IZA DP No. 8007

Remittances and Child Labour in Africa: Evidence from Burkina Faso

Olivier Bargain

Delphine Boutin

February 2014 


\title{
Remittances and Child Labour in Africa: Evidence from Burkina Faso
}

\author{
Olivier Bargain \\ Aix-Marseille University (Aix-Marseille School of Economics), \\ CNRS \& EHESS and IZA \\ Delphine Boutin \\ CERDI, University of Auvergne \\ and IZA
}
Discussion Paper No. 8007
February 2014
(revised: October 2014)

\author{
IZA \\ P.O. Box 7240 \\ 53072 Bonn \\ Germany \\ Phone: +49-228-3894-0 \\ Fax: +49-228-3894-180 \\ E-mail: iza@iza.org
}

\begin{abstract}
Any opinions expressed here are those of the author(s) and not those of IZA. Research published in this series may include views on policy, but the institute itself takes no institutional policy positions. The IZA research network is committed to the IZA Guiding Principles of Research Integrity.

The Institute for the Study of Labor (IZA) in Bonn is a local and virtual international research center and a place of communication between science, politics and business. IZA is an independent nonprofit organization supported by Deutsche Post Foundation. The center is associated with the University of Bonn and offers a stimulating research environment through its international network, workshops and conferences, data service, project support, research visits and doctoral program. IZA engages in (i) original and internationally competitive research in all fields of labor economics, (ii) development of policy concepts, and (iii) dissemination of research results and concepts to the interested public.
\end{abstract}

IZA Discussion Papers often represent preliminary work and are circulated to encourage discussion. Citation of such a paper should account for its provisional character. A revised version may be available directly from the author. 
IZA Discussion Paper No. 8007

February 2014 (revised: October 2014)

\section{ABSTRACT \\ Remittances and Child Labour in Africa: Evidence from Burkina Faso*}

This paper explores the effects of remittance receipt on child labour in an African context. We focus on Burkina Faso, a country with a high prevalence of child labour and a high rate of migration. Given the complex relationship between remittance receipt and household time allocation decisions, we instrument remittances using economic conditions in remittancesending countries and explore heterogeneous effects across different types of potential remitters. While remittances have no significant effect on child labour on average, transfers reduce child labour in long-term migrant households, for whom the disruptive effect of migration is no longer felt. We find no gender difference but remittances seem to affect mainly the labour market participation of younger children.

JEL Classification: F24, I25, J22

Keywords: remittances, migration, child labour, Africa

Corresponding author:

Delphine Boutin

CERDI

65 Boulevard F. Mitterrand

Boite Postale 320

63009 Clermont-Ferrand CEDEX 1

France

E-mail: delphine.boutin@udamail.fr

\footnotetext{
"We would like to thank participants to the 2013 Norface-CREaM Conference on Migration, to the XVI IEA World Congress, to the 63rd AFSE conference, to the 5th Journées du développement du Gretha and to various seminars for theirs insightful comments on this paper. The data and code used in the paper are available upon request from the authors.
} 


\section{Introduction}

The extent of remittances in Africa has attracted increasing attention from international organisations and from the economic literature. About 30 million Africans, according to official statistics, live today outside their home country (World Bank, 2010). A substantial fraction of these labour migrants send a part of their income to their families or relatives left behind. For many poor families, these transfers constitute a vital "financial lifeline", guaranteeing a sustainable living standard. Another source of income smoothing is the reliance on child labour, still persistent and prevalent in many African countries. Recent estimates highlight that 30.3\% of African children aged 5 to 17 years old were still economically active in 2012 (ILO, 2013). As poverty and household vulnerability are the oft-mentioned determinants of child labour (Basu and Van, 1998), remittances are likely to affect children's time allocation. However, the real impact of remittances on child labour is ambiguous and differs whether the transfers are perceived as a complementary or replacement income.

The present paper aims to analyse whether remittances act as a substitute for child labour. The empirical challenge consists in assessing the causal effect of remittance receipt on child work. We opt for an instrumental variable approach. Precisely, we obtain exogenous variation in remittance amounts using expected income and employment conditions in actual or potential migrant sending countries. This empirical strategy has been successfully applied when studying the effect of migration decisions on child labour and schooling (Antman, 2011a) or the effect of remittance receipt on schooling (Amuedo-Dorantes and Pozo, 2010, and Amuedo-Dorantes et al., 2010). Many other empirical papers have emphasized the positive role of remittances on school attendance (for instance Cox Edwards and Ureta, 2003; Acosta, 2011; Calero et al., 2009; or Yang, 2008), but few have focused on child labour. Among exceptions we are aware of, Alcaraz et al. (2012) study the effect of remittances from the US on child labour in Mexico; Acosta (2011) explores the role of remittances from international migrants on labour supply of family members in El Salvador; and Calero et al. (2009) show that remittances via transnational networks reduce the incidence of child work in Ecuador.

This paper expands the existing literature in three ways. First, while the small literature on remittances and children's time allocation has focused on the Latin American and Caribbean region, its findings can hardly be generalized to Africa. These two regions differ widely in terms of standards of living, credit and labour market imperfections and access to social programs. Because of these differences, African households rely more on both remittance receipt and child work to meet the various needs of the family. In addition, norms regarding child labour differ between the two regions, in the sense that African parents more often view child work as a form of education and value transmission, while child labour tends to disappear from Latin American countries (ILO, 2013). Against this background, we suggest the first assessment of the link between remittances and child labour in an African context.

Second, the literature often confounds the impact of migration with the effect of remittance receipt on children's outcome. These two events may in fact have opposite consequences: while 
remittances are generally expected to alleviate household budget constraints and reduce child labour, the migration of a family member may imply the need for replacement labour force in the left-behind household (see for instance Antman, 2011a). Remittance and migration effects are difficult to identify, as they may be influenced by the same factors. Yet some variation exists that can be used to isolate each effect. For instance, for the Dominican Republic, Amuedo-Dorantes and Pozo (2010) estimate the remittance effect on households without declared migrants, i.e. potentially receiving remittances from non-family members. We adopt a related strategy adjusted to our African context, which differs mainly by the fact that a majority of households have a migrant. With the aim to disentangle the mere impact of remittances from the disruption due to the loss of a productive adult member, we distinguish between long-term and short-term migrant households, assuming that the former have adjusted over time to the absence of the migrant.

Finally, while some of the previous studies only avail of partial information on remittances and migrants' characteristics, we benefit from a unique dataset, the Migration and Remittances Household Survey conducted by the World Bank in 2010 in Burkina Faso. This survey was specifically designed to fill the knowledge gap on magnitude, causes and impacts of migration and remittances in Sub-Saharan Africa (Plaza et al., 2011). More precisely, this survey provides extensive information on remittances and the characteristics of different types of migrants and their family. Burkina Faso is especially interesting for it shows a high prevalence of child labour (a national rate of $47 \%$ according to ILO, 2013). At the same time, we exploit the fact that having a migrant, which concerns two-thirds of the surveyed households, does not necessarily imply remittance receipt (only half of the households receive remittances).

As a brief preview of our results, we find that receiving remittances does not significantly impact child labour on average. However, remittance receipt from permanent migrants, for whom we rule out the negative effect of migration, significantly reduces child labour. Depending on the specification, average remittance amounts decrease the rate of child labour by $5 \%-11 \%$. This is of a similar order but noticeably larger than previous estimates for Latin America. The remittance receipt among recent migrant households is insignificant, which may reflect a different usage of remittances in this group and the fact that positive effects are offset by the recent migration of family members. While we find no differential remittance effect between boys and girls, the age of children seems to matter. Among permanent migrant households, the remittance effect is driven by the group of younger children (5-10 years old), suggesting a progressive integration of children into work activities.

The paper is organized as follows: Section 2 describes the potential links between remittance receipt and child labour while Section 3 presents the data and descriptive information. We explain the empirical strategy in Section 4 and discuss our results and robustness checks in Section 5. Section 6 concludes. 


\section{Remittances and Child's Time Allocation: A Short Review}

\subsection{The Ambiguous Effect of Remittances}

We first discuss the complex link between remittances and child labour. The most obvious and direct effect of remittances consists in increasing the disposable income of recipient households (Lucas, 2004). Remittances may help the family to reach a subsistence level and, hence, make child labour unnecessary (Basu and Van, 1998). Besides, the extra income from remittance transfers may also free up some money which can be spent on education, particularly to finance direct and opportunity costs of schooling (Giulanio et al., 2009). Various studies have shown that remittances are associated with an increase in school attendance (see Cox Edwards and Ureta, 2003, and other studies cited in the introduction). Indeed, in the context of imperfect financial markets, investment in education is typically compromised by income variability (Beegle et al., 2006) and tends to increase with alternative/external funding sources such as remittances. However a greater probability of attending school does not necessarily means a lower probability to work, especially in an African context (Edmonds and Pavcnik, 2005). A significant proportion of African children cumulate both work and studies (ILO, 2013).

Remittances can be used as a diversification device to mitigate adverse impacts on household resources (Edmonds, 2006), constituting an additional adjustment variable in case of shocks and possibly reducing the reliance on child labour. Several studies indeed show that among the strategies used to anticipate or cope with shocks, one consists in varying the supply of child labour depending on needs (Edmonds and Pavcnik, 2005; Dumas, 2007). Remittances can also be used to diversify income sources and smooth consumption (Yang, 2008). In effect, remittances are sometimes found to be counter-cyclical (Ratha, 2005), with an increase in transfers observed after a region is hit by natural disasters, conflicts or an economic crisis (Ebeke, 2010). Yet, while remittances would mitigate the use of child labour following such a shock, their relationship is hard to establish on the basis of pure cross sectional data, as both may increase simultaneously. In addition, remittances may not be high enough to prevent the increase of child labour in case of shocks, as evidenced by Calero et al. (2009) in the case of Ecuador.

In the longer term, remittances can modify household production and investment behaviour. By relaxing financial constraints, remittances are likely to encourage investments in physical capital and notably inputs in microenterprises (see Rapoport and Docquier, 2006). The effect on child labour is therefore ambiguous, especially in rural areas. Remittances can be used to purchase labour-saving equipment, possibly decreasing the reliance on child labour (Acharya and LeonGonzalez, 2013). Conversely, capital investments may require an increase in complementary inputs and notably in labour force recruited among family members. Increasing the production capacity of small household farms may have the same consequence on child labour. Incentives to hire their own children are large in the absence of perfect land and labour markets (Bhalotra and Heady, 2003; Boutin, 2012, Dumas, 2013; Basu, Das and Dutta, 2010). 


\subsection{Remittances versus Migration Effects}

The issue is getting even more complex when the effect of remittances is muddled with the consequences of migration. A robust evaluation of the impact of remittances on children's outcomes needs to make this distinction. As mentioned in the introduction, remittances and migration indeed affect household time allocation differently. By relaxing constraints on income and capital, remittances can help migrants' families improve their living standards. At the same time, migration can introduce new vulnerabilities. Migration of productive family members may have disruptive effects on the life of a household. Children may engage in economic activities to compensate the lost income or to replace the absent parent in his former activity. Antman (2011a) finds for instance that Mexican children increase work hours in the short run in response to a father's migration to the US. The absence of a parent due to migration is also likely to have consequences on children's psycho-social development and their performance at school, with some consequences on their participation to economic activities (Antman, 2012; Bansak and Chezum, 2009; Cox Edwards and Ureta, 2003). As discussed in the introduction, we focus specifically on the remittance effect among permanent migrant families, which have supposedly adapted to the adverse effect of migration.

\section{Data and Descriptive Facts}

\subsection{Data and Sample Selection}

We use data from the Migration and Remittances Household Survey, conducted in Burkina Faso by the Africa Migration Project in 2010. This comprehensive survey provides detailed information on migrants as well as on their households, including demographics, remittance receipt, housing conditions, assets, expenditures and work situation of household members including children.

The sampling frame of the survey does not cover the whole population in the country: only areas with a high incidence of migration were surveyed, based on the 2006 population census. Urban regions were under-represented (only 5\% of surveyed households lived in urban areas), simply because they contain fewer migrant-sending households than rural areas. For this reason, we focus our analysis on rural households. In addition, we select only households with children aged 5 to 14 years old (consistently with the child labour definition by ILO, 2013). As explained in more detail below, we distinguish three types of households according to the nature of their potential remitters: long-term (or permanent) migrant households, short-term (or recent) migrant households and non-migrant households. Migrant households represent the majority of cases and constitute our focus group. We define a migrant as a household member who has left home at least 6 months prior to the survey according to the household head. ${ }^{1}$ Permanent (resp. recent) migrants are defined as ex-family members who migrated more (resp. less) than 5 years prior to the survey. This threshold corresponds to the median of the number of years since migration. ${ }^{2}$ Yet, this is an arbitrary cut-off and we shall assess the sensitivity of our results to the threshold definition in our robustness analysis. 
We consider that a child is working, i.e. participates in economic activities, if he/she is declared to be "paid-employed" or "self-employed" in our data. Less than $1 \%$ of the working children are in the first category (paid workers) while the second (self-employment) corresponds to unpaid family work and certainly to unpaid work on the family farm, given our focus on rural households. This intuition is confirmed by looking at the current industry in which these children work: $98 \%$ of the "self-employed" are also employed in "Agricultural, forestry and fishery work". We unfortunately have no information on domestic work (another form of unpaid family work) or on the number of working hours, which prevents us from exploring the effect of remittances on this margin. For the rest of the study, the variables of interest are the proportion of working children per household (household-level estimations) and a dummy for child work (child-level estimations).

\subsection{Descriptive Analysis}

The original survey contains 2,102 households. As explained above, selection consists in excluding urban households (-5\% of the initial sample) and households without children aged 5-14 $(-7 \%)$. We also discard observations when necessary information was missing (-10\%). We obtain a final sample of 1,627 households, corresponding to 5,344 children.

Table 1 presents the main descriptive statistics of the potential remitters in the selected sample, i.e. migrants in permanent/recent migrant households, who may remit or not, and actual remitters in non-migrant households (other non-migrant households can have potential remitters but the latter are unknown to the analyst).

Migrants are most often young males, siblings or children of the head, often with no education and characterized by work-oriented migration motives. Permanent and recent migrants are not fundamentally different with respect to observed characteristics. Mechanically, permanent migrants are significantly older, yet the age at departure is relatively close. The main difference between the two migrant groups pertains to the relationship to household heads: long-term migrants are more often siblings of the head. In contrast, remitters in non-migrant households represent a quite different group. They are more often female, slightly less educated and, by construction, nonrelatives or distant relatives who never lived in the household. Admittedly, this may induce different remitting behaviour. 
Table 1: Potential Remitters' Characteristics

\begin{tabular}{|c|c|c|c|}
\hline & \multicolumn{2}{|c|}{ For Migrant households } & \multirow{2}{*}{$\begin{array}{c}\text { For Non-migrant } \\
\text { households* }\end{array}$} \\
\hline & $\begin{array}{l}\text { Permanent } \\
\text { migrants }\end{array}$ & Recent migrants & \\
\hline \multicolumn{4}{|l|}{ Demographics } \\
\hline Male $(\%)$ & 0.96 & 0.93 & 0.83 \\
\hline Age at survey time (mean) & 0.37 & 0.30 & n.a. \\
\hline Age at migration (mean) & 0.26 & 0.28 & n.a. \\
\hline \multicolumn{4}{|c|}{ Relationship to the household head (\%) } \\
\hline Spouse & 0.02 & 0.03 & 0.0 \\
\hline Son/Daughter & 0.40 & 0.54 & 0.0 \\
\hline Father/Mother & 0.10 & 0.07 & 0.0 \\
\hline Brother/Sister & 0.44 & 0.31 & 0.33 \\
\hline Other Relative & 0.04 & 0.05 & 0.51 \\
\hline Non-Relative & 0.01 & 0.00 & 0.17 \\
\hline \multicolumn{4}{|l|}{ Education level (before migration) } \\
\hline None & 0.60 & 0.58 & 0.63 \\
\hline Primary & 0.40 & 0.43 & 0.37 \\
\hline Secondary or higher & 0.00 & 0.00 & 0.00 \\
\hline \multicolumn{4}{|l|}{ Primary reason for migration (\%) } \\
\hline Education & 0.10 & 0.10 & n.a. \\
\hline Search for work & 0.78 & 0.77 & n.a. \\
\hline Job transfer/job opportunity & 0.02 & 0.02 & n.a. \\
\hline Marriage arrangement & 0.03 & 0.04 & n.a. \\
\hline Others reasons & 0.08 & 0.07 & n.a. \\
\hline No. corresponding households & 455 & 594 & 578 \\
\hline$\%$ households with actual remitters & 0.60 & 0.57 & 0.24 \\
\hline
\end{tabular}

All statistics refer to potential remitters in our selected sample (rural households with children aged 5-14).

* For non-migrant households, these are the characteristics of the actual remitters.

Source: Migration and Remittances Household Survey, Burkina Faso, 2010

Table A1 in the Appendix reports additional statistics about remittances. Regarding the distribution of channels used to send remittances, non-migrant households show a clearly different pattern compared to permanent/recent migrant households. In the latter group, remittances are mainly sent through friends and, to a lesser extent, by the remitter himself. Remitters' visit is more frequent in non-migrant households and we can conjecture that remitters have more control on the use of remittances. Table A1 also reports the allocation of remittance money across different types of expenditure items. Consistent with previous studies (Rapoport and Docquier, 2006; Yang, 2008), remittances are mainly used to finance normal and necessary goods, especially food. In relation with our discussion in section 2.1, we can suppose that remittances replace some of the child production in farm goods consumed by the household. A substantial share of the received remittances are also used on goods that directly affect children, like education and health. The extent to which child labour is affected by these transfers is however unknown and the purpose of our empirical investigation. 
Table 2: Household's Characteristics

\begin{tabular}{|c|c|c|c|c|c|c|}
\hline & \multicolumn{2}{|c|}{ Permanent migrant households } & \multicolumn{2}{|c|}{ Recent migrant households } & \multicolumn{2}{|c|}{ Non-migrant households } \\
\hline & Mean & Std. Dev. & Mean & Std. Dev. & Mean & Std. Dev. \\
\hline \multicolumn{7}{|l|}{ Household Characteristics } \\
\hline Age of household head & 52.2 & 15.0 & 51.8 & 14.0 & 44.4 & 12.6 \\
\hline Female headship (\%) & 0.05 & 0.21 & 0.06 & 0.23 & 0.04 & 0.20 \\
\hline Head is employed (\%) & 0.95 & 0.20 & 0.96 & 0.18 & 0.98 & 0.13 \\
\hline Head has no education (\%) & 0.90 & 0.29 & 0.89 & 0.32 & 0.88 & 0.32 \\
\hline Household size & 10.1 & 4.5 & 10.2 & 4.7 & 8.5 & 4.0 \\
\hline \# children 5-14 & 3.4 & 1.9 & 3.5 & 2.0 & 3.0 & 1.8 \\
\hline Log of household expenditure & 13.7 & 1.4 & 13.8 & 0.8 & 13.6 & 1.0 \\
\hline Asset index \$ & 5.7 & 2.1 & 5.5 & 2.0 & 5.3 & 2.2 \\
\hline Moslim (\%) & 0.64 & 0.48 & 0.59 & 0.49 & 0.60 & 0.49 \\
\hline Mossi ethnic group (\% ) & 0.74 & 0.43 & 0.71 & 0.45 & 0.69 & 0.46 \\
\hline Number of adult employed & 3.4 & 2.3 & 3.6 & 2.2 & 2.8 & 1.8 \\
\hline Business ownership (\% ) & 0.24 & 0.43 & 0.21 & 0.41 & 0.15 & 0.36 \\
\hline \multicolumn{7}{|l|}{ Village Characteristics } \\
\hline Size & 552 & 319 & 487 & 296 & 501 & 306 \\
\hline$\%$ migrants per village & 0.07 & 0.01 & 0.07 & 0.01 & 0.07 & 0.01 \\
\hline $\begin{array}{l}\% \text { adult employed per village } \\
\text { Remittance Receipt }\end{array}$ & 0.34 & 0.06 & 0.35 & 0.07 & 0.34 & 0.06 \\
\hline Ever received remittances (\%) & 0.60 & 0.49 & 0.57 & 0.50 & 0.24 & 0.43 \\
\hline Mean amount received over the year (incl. zeros)* & 47,776 & 94,642 & 47,259 & 114,043 & 12,596 & 57,086 \\
\hline Mean amount received over the year (excl. zeros) ${ }^{*}$ & 79,927 & 111,478 & 82,808 & 140,945 & 52,755 & 107,662 \\
\hline $\begin{array}{l}\text { Number of transfers over the year (excl. zeros) } \\
\text { Child Time Use }\end{array}$ & 1.35 & 1.40 & 1.32 & 1.14 & 1.53 & 1.04 \\
\hline Child labour rate (child-based measure) & 0.29 & 0.48 & 0.40 & 0.49 & 0.41 & 0.49 \\
\hline \multicolumn{7}{|l|}{ Mean proportion of children at work in the household: } \\
\hline All households & 0.26 & 0.30 & 0.39 & 0.37 & 0.40 & 0.38 \\
\hline Remittance receiving households & 0.21 & 0.23 & 0.40 & 0.36 & 0.39 & 0.37 \\
\hline Non remittance receiving households & 0.33 & 0.37 & 0.39 & 0.38 & 0.40 & 0.39 \\
\hline \multicolumn{7}{|l|}{ Mean proportion of children in education in the household: } \\
\hline All households & 0.53 & 0.36 & 0.46 & 0.36 & 0.41 & 0.37 \\
\hline Remittance receiving households & 0.57 & 0.34 & 0.47 & 0.35 & 0.42 & 0.37 \\
\hline Non remittance receiving households & 0.46 & 0.38 & 0.45 & 0.38 & 0.40 & 0.37 \\
\hline No. of households & & & & & & \\
\hline
\end{tabular}

$\$$ Assets measured on a 0-20 scale (sum of binary variables for ow nership of 20 different agricultural and non-agricultural assets).

* Remittance amounts are in CFA divided by 1,000,000.

All statistics refer to the selected sample (rural households with children aged 5-14)

Source: Migration and Remittances Household Survey, Burkina Faso, 2010 
Table 2 reports household characteristics. We particularly focus our attention to migrant households, to which two-thirds of the children in our sample belong and in which $82 \%$ of children in remittance-receiving households reside. Table 2 shows that in this group, permanent and recent migrant households share similar demographics (age of household head, household size and mean number of children in particular - see also Figure A1 in the Appendix for the age distribution of children), labour market characteristics and wealth measures (the log of expenditure and the asset measure). Non-migrant households are relatively different and notably younger, smaller and poorer. All groups live in villages with similar characteristics regarding migration and employment rates. Not surprisingly, remittance receipts are very different in non-migrant households. The proportion of households who ever received remittances is only $24 \%$ in this group against $60 \%$ and $57 \%$ in permanent and recent migrant households respectively. Remittance amounts are also much smaller: 52,000 CFA Francs for the former against around 80,000 CFA Francs for migrant households on average.

With our definition based on 5-14 year-old children, we find a rate of child labour of $37.5 \%$ for the ten provinces covered in the survey. It considerably varies between the three household types, from $29 \%$ in permanent migrant households up to $41 \%$ in non-migrant households. A similar pattern emerges with the mean proportion of working children within households (from $26 \%$ up to $40 \%$ ). For recent migrant households, the high prevalence of child labour might reflect the deleterious effect of migration on child work. Different child labour rates might also be due to a composition effect, which is certainly the key explanation for non-migrant households. Table 2 additionally shows that among permanent migrant households, the proportion of child labour is substantially smaller in receiving households. This could suggest a reducing effect of remittances on child work. The rest of the paper attempts to estimate remittance effects when controlling for households characteristics and addressing the potential endogeneity of remittance receipts. Child labour appears much less elastic to remittance receipt among recent migrant households, and even less so among non-migrant households. For these two groups, education enrolment also changes very little with remittance receipt.

\section{Empirical Approach}

We specify the child labour supply function as follows:

$$
Y_{j}=\beta_{0}+\beta_{1} R_{j}+\beta_{2} X_{j}+\varepsilon_{j}
$$

where $Y_{j}$ is the proportion of working children in household $j$ (household-level estimations) or the binary work status of a child $j$ (child-level estimations); $R_{j}$ is the amount of remittances or a binary variable equal to 1 if the household receives remittances; $X_{j}$ is a vector of household characteristics (as listed in Table 2), village characteristics (adult employment rate and migration rate) and province dummies. Residuals $\varepsilon_{j}$ are assumed to be random and normally distributed. Coefficient $\beta_{1}$ captures the effect of remittance receipt. 
Our main econometric challenge lies in the endogeneity of remittance receipt $R_{j}$. For the sake of exposition, assume that the true coefficient $\beta_{1}$ is negative, i.e. remittance receipt reduces the extent of child labour. Estimates of $\beta_{1}$ may possibly be upward biased, i.e. be less negative than expected or even positive. This can be due to omitted unobservables like specific shocks that simultaneously force the household to rely more on child labour and to claim more remittances from its migrants. Another source of positive correlation between remittance receipt and child labour results from reverse causality or the potential joint determination of remittance transfers and child work. For instance, child labour can act as a signal of household poverty which induces remittance inflows by migrated relatives. In all these cases, we would simply underestimate the remittance effect. More problematic, a downward bias could also occur and lead us to wrongly conclude about the reducing effect of remittances on child labour. Such a bias may be due for instance to a common shock affecting both the migrant's location and the household's place of residence, especially when the migrant lives in a nearby region. In effect, in this case, a bad economic situation could both hinder the possibility to remit by the migrant and increase the reliance on child labour by the left-behind household.

We opt for an instrumental variable strategy to address this endogeneity issue and identify the causal impact of remittances on child labour. In the literature, two instruments have been used that specifically provide exogenous variation in remittance amounts: transaction costs of transferring funds (see Calero et al., 2009) and exchange rate variation (Yang, 2008). The former is irrelevant in the African context (as seen in Table A1, the majority of remittances flow through informal channels) while the latter would require time variation. Instead we use variation in economic conditions and labour market shocks at migrants' destination. Variation in expected earnings and labour market conditions in destination areas is also used by Amuedo-Dorantes and Pozo (2010) and Amuedo-Dorantes et al. (2010) to assess the effect of remittances on schooling in Haiti and the Dominican Republic respectively. Labour market shocks are used by Adams and Cuecuecha (2013) to gauge the impact of remittances on investment and poverty in Ghana. Our identifying assumption is that recent economic conditions or labour shocks at destination affect the probability of receiving remittances but are not correlated with the decision to put children into work.

In the Migration and Remittances Survey, eighteen remittance-sending countries or regions are identified, namely rural and urban Burkina Faso, Côte d'Ivoire, Mali, Niger, Ghana, Togo, Benin, Nigeria, Gabon, Libya, others African countries, Italy, France, Germany, Switzerland, USA and other countries. Each migrant household is asked to report the current and past locations of their migrants. Each non-migrant household receiving remittances also report the location of their remitter. For other non-migrant households, we impute the destination region and other characteristics of a potential remitter using the modes of the distributions for these variables in the sub-sample of non-migrant households receiving remittances. Our two instruments are then constructed from this information and from World Bank indicators on income and employment rates. The first instrument (IV1) refers to the mean expected earnings in sending countries over the past 3 years (2007-2009), calculated as mean income multiplied by mean employment rate. The second instrument is based on contemporary labour shock in destination countries. Precisely, we construct a time-series variable on employment creation in remittance-sending countries from 1999 to 2008 to predict job creation rates for the year 2009 using an AR(1) process. Thus, we can 
recover the unexpected rate of job creation, a proxy for exogenous labour market shocks, as the difference between actual and predicted job creation rates in 2009 .

Two limitations may come to mind with this approach. The first one is related to the bias due to common shocks possibly experienced by both the migrants and their left-behind households, as discussed above. In fact, a substantial fraction of migrants are themselves located in Burkina Faso (42\%). We provide thereafter some robustness checks regarding this issue, distinguishing across regions within the country (rural or urban destinations) and types of migrants (national or international). A second potential issue holds in the fact that regions of destination could be correlated with economic conditions in origin communities and/or household characteristics (especially with household wealth). ${ }^{3}$ In fact, all our specifications control for employment and migration rates in the village where the household resides, as well as for relevant household characteristics. In particular we include proxies of household standards of living (log expenditure) and permanent income (an asset index captures the relatively long-term economic status of the household, which is less correlated with short-term determinants of household resources including remittances and child labour). Arguably, destination regions might also be correlated with unobservable household characteristics. For instance, households with better information are more likely to send migrants in places with better labour markets. While this could affect IV1, IV2 aims at using unexpected variation in labour market conditions at destination to address this concern.

The average remittance effect may hide contrasted situations as discussed in section 2.1. In particular, it may differ when taking into account the length of migrant's absence. As noted in the introduction and discussed in section 2.2, the impact of remittances is often muddled by the effect of migration, which may be of opposite sign if households rely on child labour to replace a migrant recently left. Our approach is related to that of Amuedo-Dorantes and Pozo (2010). For the Dominican Republic, they estimate the remittance effect on households without declared migrants (i.e. potentially receiving remittances from non-family members) and assess the migration effect by comparing households with and without migrated family members. Their strategy is justified by the fact that $88 \%$ of children live in non-migrant households. Our context is different as migrant households represent two-thirds of our sample - and hence shall be our focused group. In the minority of non-migrant households, remittances from friends or distant relatives may serve a fundamentally different purpose compared to transfers by relative migrants. To distinguish potentially heterogeneous effects, we conduct estimations on our full selected sample but interact remittance receipt with household types. Denote permanent migrant, recent migrant and nonmigrant households by the dummies $\mathrm{Perm}_{j}, \operatorname{Rec}_{j}$ and $\mathrm{Non}_{j}$ respectively, we estimate:

$$
Y_{j}=\beta_{0}+\beta^{\text {perm }} \operatorname{Perm}_{j} . R_{j}+\beta^{r e c} \operatorname{Rec}_{j} . R_{j}+\beta^{n o n} \operatorname{Non}_{j} . R_{j}+\beta_{2} X_{j}+\eta^{r e c} \operatorname{Rec}_{j}+\eta^{n o n} N_{o n}+\varepsilon_{j}
$$

where $\beta^{\text {perm }}, \beta^{\text {rec }}$ and $\beta^{\text {non }}$ now capture different remittance effects. We particularly focus on the effect among migrant households, for whom migration already took place and is taken as exogenous. We also assume unconfoundedness when comparing permanent and recent migrant households, i.e. we take migration duration as exogenous after conditioning on household characteristics. In this way, we only instrument remittance receipt $R_{j}$ for which exogenous variations are provided by economic conditions at destination, as explained above. ${ }^{4}$ With this approach, our aim is simply to provide illustrative evidence of the importance of distinguishing 
between the presumably aggravating migration effect and the reducing remittance effects when examining the impact of remittance inflows on children's labour market participation in Burkina Faso. In order to purge the coefficient estimate of remittance-receipt from any potential disruptive effect of contemporaneous family migration, we shall focus on $\beta^{\text {perm }}$, that is, the effect among longterm migrant households. Coefficient $\beta^{\text {rec }}$ could reflect to what extent the gains from remittances make up or not for the losses sustained from family migration. In addition, "group effects" $\eta$ may be informative about how child labour levels differ once controlling for observed characteristics.

\section{Empirical Results}

\subsection{Impact of Remittance Receipt on Child Labour: Main Results}

In the following tables, we present evidence from OLS and IV estimations using the two instrumentation strategies described in the previous section. We only report the point estimates of the remittance receipt coefficients $\beta$ and of group effects $\eta$, their standard errors, and the coefficients on instrumental variables in the first-stage equation. ${ }^{5}$ Table 3 reports estimations at household-level whereby the dependent variable is the proportion of working children in the household. In our favourite specification (first two panels of Table 3 ), $R_{j}$ is the annual amount of remittances received by households including zeros, which captures both the effect of receiving remittances (extensive margin) and the effect of remittance levels (intensive margin).

We first ascertain the econometric relevance of our instruments. First-stage estimates are reported in the lower panel of Table 3. They are statistically different from zero at the $1 \%$ level for both IV1 and IV2, suggesting that our instruments are significant predictors of remittance amounts. They show positive effects on remittance receipt, meaning that both higher expected earnings and a positive employment shock boost the remittances that migrants can afford to send to their villages of origin. F-statistics are larger than the common threshold of 10 in both specifications, indicating that we are not in presence of weak instruments.

Turning to our main results, the first row of Table 3 reports the overall effect of remittance receipt on child labour, i.e. $\beta_{1}$ in equation (1). We observe a negative effect in OLS estimations, yet insignificant, and hardly any effect in both IV1 and IV2. This result is reminiscent of AmuedoDorantes and Pozo (2010) and Acosta et al. (2007) regarding child schooling. These authors find that remittance receipts have no effect (on schooling) overall. Amuedo-Dorantes and Pozo conclude about the possibly conflicting migration effect among migrant households. In our case, this disruptive effect would be driven only by recent migrant households, around a third of the sample. We cannot preclude that other factors are at play and notably different remittance behaviour (and lower remittance amounts) among non-migrant households. Nonetheless, we reach the same conclusion when replicating our estimations on the sub-group of migrant households (two-thirds of our sample). That is, among migrant households as a whole, remittances hardly affect child labour 
Table 3: Impact of Remittance Receipt on Child Labour (Household-level Estimations)

\begin{tabular}{|c|c|c|c|}
\hline Dep. variable: Propotion of children at work in the household & OLS & IV1 & IV2 \\
\hline \multirow[t]{2}{*}{ Overall remittance effect, total effect ${ }^{\text {(a) }}$} & -0.120 & -0.022 & 0.015 \\
\hline & $(0.076)$ & $(0.163)$ & $(0.165)$ \\
\hline \multicolumn{4}{|l|}{ Heterogenous remittance effects ${ }^{(a)}$} \\
\hline \multirow[t]{2}{*}{ Remittances x Permanent } & $-0.254^{*}$ & $-0.734^{* * *}$ & $-0.702^{* * *}$ \\
\hline & $(0.137)$ & $(0.258)$ & $(0.271)$ \\
\hline \multirow[t]{2}{*}{ Remittances $x$ Recent } & -0.010 & 0.036 & 0.056 \\
\hline & $(0.101)$ & $(0.199)$ & $(0.198)$ \\
\hline \multirow[t]{2}{*}{ Remittances $x$ Non-Migrant } & -0.216 & -0.186 & -0.258 \\
\hline & $(0.201)$ & $(0.294)$ & $(0.312)$ \\
\hline \multicolumn{4}{|l|}{ Group effect $^{(\$)}$} \\
\hline \multirow[t]{2}{*}{ Recent } & $0.082^{* * *}$ & $0.057^{\star *}$ & $0.057^{\star *}$ \\
\hline & $(0.019)$ & $(0.023)$ & $(0.023)$ \\
\hline \multirow[t]{2}{*}{ Non-Migrant } & $0.058^{* * *}$ & 0.035 & $0.038^{*}$ \\
\hline & $(0.019)$ & $(0.022)$ & $(0.022)$ \\
\hline \multicolumn{4}{|l|}{ Heterogenous remittance effects, extensive margin ${ }^{(b)}$} \\
\hline \multirow[t]{2}{*}{ Remittances $x$ Permanent } & $-0.057^{* *}$ & $-0.156^{*}$ & $-0.202^{* *}$ \\
\hline & $(0.027)$ & $(0.090)$ & $(0.092)$ \\
\hline \multirow[t]{2}{*}{ Remittances x Recent } & 0.022 & -0.122 & -0.125 \\
\hline & $(0.023)$ & $(0.089)$ & $(0.092)$ \\
\hline \multirow[t]{2}{*}{ Remittances x Non-Migrant } & 0.009 & -0.077 & -0.121 \\
\hline & $(0.027)$ & $(0.080)$ & $(0.084)$ \\
\hline \multicolumn{4}{|l|}{ Group effect ${ }^{(\$)}$} \\
\hline \multirow[t]{2}{*}{ Recent } & $0.048^{*}$ & $0.050^{*}$ & $0.049^{*}$ \\
\hline & $(0.027)$ & $(0.026)$ & $(0.026)$ \\
\hline \multirow[t]{2}{*}{ Non-Migrant } & 0.031 & 0.007 & 0.019 \\
\hline & $(0.024)$ & $(0.025)$ & $(0.025)$ \\
\hline \multicolumn{4}{|l|}{ Heterogenous remittance effects, intensive margin ${ }^{(c)}$} \\
\hline \multirow{2}{*}{ Remittances x Permanent } & $-0.265^{*}$ & $-0.906^{* * *}$ & $-0.772^{* *}$ \\
\hline & $(0.141)$ & $(0.305)$ & $(0.307)$ \\
\hline \multirow[t]{2}{*}{ Remittances x Recent } & -0.017 & -0.101 & 0.005 \\
\hline & $(0.104)$ & $(0.237)$ & $(0.224)$ \\
\hline \multirow[t]{2}{*}{ Remittances x Non-Migrant } & -0.230 & -0.315 & -0.314 \\
\hline & $(0.206)$ & $(0.318)$ & $(0.333)$ \\
\hline \multicolumn{4}{|l|}{ Group effect ${ }^{(\$)}$} \\
\hline \multirow[t]{2}{*}{ Recent } & $0.082^{* * *}$ & $0.055^{* *}$ & $0.057^{* *}$ \\
\hline & $(0.019)$ & $(0.023)$ & $(0.023)$ \\
\hline Non-Migrant & $0.059^{* * *}$ & $0.036^{*}$ & $0.038^{*}$ \\
\hline & $(0.020)$ & $(0.022)$ & $(0.022)$ \\
\hline First stage equation & & & \\
\hline Effect of instruments on remittance receipt ${ }^{(d)}$ & & $0.103^{* * *}$ & $0.145^{* * *}$ \\
\hline & & $(0.023)$ & $(0.036)$ \\
\hline F-stat & & 17.49 & 13.48 \\
\hline Prob $P>F$ & & 0.00 & 0.00 \\
\hline $\mathrm{N}$ & 1,627 & 1,627 & 1,627 \\
\hline $\begin{array}{l}\text { All estimations control for household characteristics and provinc } \\
\text { (a) Coefficients report the effect of remittance receipt (amounts, in }\end{array}$ & $\begin{array}{l}\text { ffects. Rem } \\
\text { uding zeros) }\end{array}$ & $\begin{array}{l}\text { amounts are } \\
\text { ild labour. }\end{array}$ & A divided by \\
\hline (b) Coefficients report the effect of remittance receipt (binary var & e) on child I & & \\
\hline (c) Coefficients report the effect of remittance receipt (amount) on & ild labour $\mathrm{w}$ & ontrolling for & ince receipt \\
\hline (d) Instruments: IV1 is mean ex pected earnings ov er 2007-2009 & $/ 2$ is the lab & ock in 2009. & \\
\hline (\$) Reference group: permanent migrant households & & & \\
\hline${ }^{* * *},{ }^{* *}$, and ${ }^{*}$ indicate significant at $1 \%, 5 \%$, and $10 \%$ respective & & & \\
\hline Source: Migration and Remittances Household Survey, B & ina Faso, & & \\
\hline
\end{tabular}


Failure to properly separate the family migration effect from the remittance effect may underestimate the reducing impact of remittance transfers on child labour. To investigate the role of remittance receipts more specifically, the second panel of Table 3 reports heterogeneous effects by type of potential remitters, as modelled in equation (2). Most interestingly, remittance receipts reduce child labour among permanent migrant households, a group for which we ruled out any disruptive effect of migration. The effect is significant in all specifications. Given that IV1 and IV2 pertain to different choices regarding the trade-off between strong and exogenous instrument, as discussed in section 4, it is reassuring to see that both give similar effects. Noticeably, IV estimates are larger than OLS, which possibly indicate an upward bias along the lines previously discussed. Regarding the magnitude of the effect, note that remittance amounts are expressed in CFA Francs divided by 1 million. For each household type, we divide the marginal effect by 1 million and multiply by the mean remittance amount (cf. Table 2) to obtain an approximation of the mean effect. For permanent migrant households, it comes that the average effect of remittances corresponds to a decrease of 1.2, 3.5 and 3.4 percentage points in the proportion of children at work using OLS, IV1 and IV2 respectively. These levels correspond to a 5.5\%, 10.3\% and $11.2 \%$ decrease, respectively, of the mean proportion of working children.

We move to other household types. As shall be seen, we find contrasted remittance effects across types of potential remitters, which illustrate some of the ambiguous patterns described in section 2. We start with recent migrant households. We observe a zero remittance effect in this group, consistent with the interpretation that remittances do not make up for the recent departure of a productive family. ${ }^{6}$ In other words, it is likely that households who attempt to smooth consumption by sending migrants abroad may also have to replace the absent worker and resort to child labour, at least in the short-run. With this interpretation, the significant and positive coefficient $\eta^{\text {rec }}$ would signify that other things being equal, having a recent migrant has a disruptive effect on child labour which translates in a 5.7-8.2 point (or 14.5\%-20.8\%) increase in the proportion of working children. On the other hand, the role of remittance transfers may also differ among recent migrant households if this group is not a random draw among all migrant households. As argued in section 4, it is beyond the scope of this paper to endogeneize migration duration. Yet we may provide suggestive evidence that this group is not fundamentally incomparable to permanent migrant households. First, recall from section 3.2 that the two groups of migrants are not so different in terms of observed characteristics (see Table 1), and so are the two groups of corresponding households (see Table 2). ${ }^{7}$ Most importantly, remittance amounts and frequency of transfers are similar in the two groups, showing that remittances do not decay with duration abroad or would be smaller because permanent migrants behave differently. Second, the main observable differences regarding migrants (Table 1) pertain to their relationship to the children living in the household. Recent migrants are more often children's siblings while permanent migration is more often due to departures of children's aunts/uncles from the household. As permanent migration may proxy for other (unobservable) differences than just the length of migration, we suggest a specification which controls for the relationship between the migrant and the child. By construction this information is available for migrant households only. Hence, we replicate our estimations with interaction effects on this sub-group, i.e. excluding non-migrant households, with and without these additional controls. In both cases, remittance effects for both permanent and recent migrant households are hardly changed compared to baseline results. ${ }^{8}$ Third, recent migrant households are 
by definition characterized by the presence of more and older children in the household at the time of (and following) migrant departure, so that these children can more easily take over the work of the migrant. ${ }^{9}$ Hence, we replicate our estimations on migrant households only, controlling for the presence of children and the average age of children at migrant departure. Remittance effects for the two groups are basically unchanged. ${ }^{10}$ These results corroborate our previous interpretations: child labour is inelastic to remittances in recent migrant households while it is aggravated by the fact that recent migrants could be replaced by children in the household.

Finally, we find a negative but insignificant remittance effect among non-migrant households. In this sense, our results depart from those of Amuedo-Dorantes and Pozo (2010), yet only because non-migrant households do not represent a majority of households in the African context under study. On the contrary, they represent a relatively specific group that we described as fairly different from migrant households in section 3.2. The insignificant remittance effect may be explained by the lower remittance levels characterizing this group or by different usage of remittance transfers (money may be directed towards more urgent necessities, rather than lifting the working load of children). Also, non-migrant families are younger and poorer, so they may not afford to send migrants abroad to diversify income sources and, at the same time, rely more extensively on child labour. Finally, as the remitters are no former household members, and not even close relatives in most cases, they may be less inclined to remit for altruistic motives targeting children of the household.

\subsection{Alternative Specifications and Robustness Check}

We suggest alternative empirical specifications. The third and fourth panels of Table 3 report extensive and intensive remittance effects. The extensive effects are obtained by replacing $R_{j}$ by a simple dummy taking value 1 if the household receives remittances. Results are qualitatively unchanged, with strong negative remittance effects among permanent migrant households, overstated OLS estimates and similar estimates for IV1 and IV2. Even if significant only for permanent migrant households, remittance effects are now negative in all three groups and relatively similar across groups. To some extent, this reflects the fact that we ignore remittance amounts in this model, which may be seen as misspecified. For permanent migrant households, the coefficient on binary $R_{j}$ (from -0.057 to -0.202 across specifications) is the effect of a switch from no remittance to (some) remittance receipt. Multiplying by the proportion of households receiving remittances in this group (cf. Table 2) gives a decrease of 3.4-12.1 percentage points of the proportion of children at work. The intensive effects reported in Table 3 are obtained with remittance amounts for $R_{j}$ but additionally controlling for binary remittance receipt, attempting to capture the pure intensive margin for those receiving remittances. The coefficients on dummy variables for remittance receipt are positive but usually insignificant (not reported) while the coefficients on $R_{j}$ resemble the estimates obtained in the baseline model.

We have also performed several robustness checks. First, alternatively to interacting household types with $R_{j}$ as described in equation (2) and presented in the baseline, we have conducted separate estimations for each type of household. Results are very similar (not reported). We have also experimented with several alternative instruments. In particular, we have used mean earnings over 
different periods other than 2007-2009 (the past 2, 4 and 5 years, and past years since migration date). We obtain very close results to baseline estimates with IV1 (not reported but available from the authors). This may indicate that the relevant source of variation is not temporal (periods) but spatial (destination regions).

This leads to another check pertaining to migrants' destinations. As briefly discussed in section 4, results can be sensitive to common shocks experienced by both the migrant and his household. To address this concern, we replicate our estimations on two alternative sub-samples. The first one excludes households with rural-to-rural or urban-to-urban migrants within Burkina Faso (this leaves us with a sample of 1,311 households). In this way, we rule out the possibility that a nearby migrant and his family experience the same shock, which would possibly affect simultaneously the ability to remit for the former and the reliance on child labour for the latter. Results are reported in the lefthand-side panel of Table B1 in the Appendix. Despite a smaller sample size, we find a similar pattern to the baseline, in particular a very comparable effect for permanent migrant households. The concern of a downward bias due to common shocks partly remains, however, if the shock takes place at the country level. Hence, the second set of results in Table B1 focuses on households with international migrants only (a sub-sample of 1,056 households remains). Reassuringly, estimates are again very similar to our main results.

Finally, we check that results are not driven by the particular threshold retained when defining permanent versus recent migrants (5 years of migration, i.e. the median). We replicate our estimations for different thresholds around that level, from 3 to 7 years of absence. ${ }^{11}$ It is difficult to conjecture how remittance effects may change with cut-off levels. Results, reported in Table B2 in the Appendix, tend to show an increase in the remittance effects for recent and permanent migrant households between 3 and 6-year thresholds and a slight decrease at 7 years. Yet these differences are small and clearly insignificant.

\subsection{Child Level Estimations and Child Heterogeneity}

We now consider estimations at child level, using a dummy for whether a child work or not as dependent variable. Our selected sample is transformed in a sample of 5,344 children. Standard errors are clustered at the household level to take into account the simultaneity of decisions within the household. Estimations are performed by linear probability model to directly read marginal effects and easily perform instrumentation (IV probit estimations nonetheless lead to very similar results). ${ }^{12}$

Estimates of the remittance effect, using remittance amounts including zeros, are reported in the first three columns of Table 4. They are broadly in line with previous results at household-level using proportions of child labour. Essentially, IV estimates are larger than OLS for children in permanent migrant households, remittance effects are negative and significant in this group, insignificant in the other groups. The magnitude of the effect in permanent migrant households is comparable to results based on household-level estimations. Coefficients translate in a mean reduction in the probability of child work of 1.2-3.2 percentage points across specifications. Taken as a ratio of the child labour rate in this group (29\%), this corresponds to a $4 \%-11 \%$ decline in the 
prevalence of child work, which is almost identical to the effect range obtained using householdlevel proportions of working children. Note that the advantage of child-level estimations is that they can be more readily compared to results in other studies, which usually report estimations of binary child labour market participation. This is the case for instance in Calero et al. (2009) and Acosta (2011) who report estimates of a similar order as ours. The former study finds that on average, remittances decrease work participation of children in Ecuador by 2 percentage points, which corresponds to a $5 \%$ decrease in the child labour rate in general $(6.5 \%$ decrease among receiving households). The latter study reports that binary remittance receipt decreases child work in El Salvador by $6.7 \%$. Nonetheless, these figures tend to be at the lower bound of our interval, indicating that remittance effects are slightly larger in an African context, at least among permanent migrant households.

The rest of Table 4 explores the possible heterogeneity of the remittance effect according to children's characteristics. We first interact the remittance amount with child gender (similar results are obtained when running estimations on boys and girls separately). The presence of gendered remittance effect is possible since the migration of male members may also affect the balance of power in the household (Antman, 2011b). Yet, as shown in Table 4, we find no statistically significant difference between boys and girls, maybe with the exception of IV1 which yields an insignificant effect for boys. Next, we investigate how remittance effects may vary with child age. We replicate estimations when interacting remittance amounts with dummies for younger children (5-10 years old) and older children (11-14 years old). Interestingly, Table 4 shows that the large negative effect of remittances on child labour among permanent migrant households is mainly driven by an effect on younger children. This may not be surprising in a rural African context characterized by labour-intensive farm activities. ${ }^{13}$ More generally, African children are steadily integrated into economics activities, all the more so as work is viewed as a form of training or transmission (Rosenzweig and Wolpin, 1985) while formal education is perceived as having low returns. ${ }^{14}$ Finally, this result may convey that different remittance effects between permanent and recent migrant households may be linked to different age distributions. Figure A1 in the Appendix shows that this is not the case. 
Table 4: Impact of Remittance Receipt on Child Labour (Child-level Estimations)

\begin{tabular}{|c|c|c|c|c|c|c|c|c|c|c|c|c|c|c|c|}
\hline \multirow[b]{2}{*}{ Dep. variable: child is in work (0/1) } & \multicolumn{3}{|c|}{ All children } & \multicolumn{3}{|c|}{ Girls } & \multicolumn{3}{|c|}{ Boys } & \multicolumn{3}{|c|}{ Younger children } & \multicolumn{3}{|c|}{ Older children } \\
\hline & OLS & IV1 & IV2 & OLS & IV1 & IV2 & OLS & IV1 & IV2 & OLS & IV1 & IV2 & OLS & IV1 & IV2 \\
\hline \multicolumn{16}{|l|}{ Heterogenous remittance effects ${ }^{(a)}$} \\
\hline \multirow[t]{2}{*}{ Remittances x Permanent } & $-0.250^{* *}$ & $-0.695^{\star * *}$ & $-0.672^{* * *}$ & -0.296 & $-0.933^{* * *}$ & $-0.851^{* *}$ & $-0.212^{* *}$ & -0.450 & $-0.595^{*}$ & $-0.419^{* * *}$ & $-0.980^{* * *}$ & $-1.118^{* * *}$ & -0.040 & -0.163 & -0.047 \\
\hline & $(0.107)$ & $(0.238)$ & $(0.244)$ & $(0.210)$ & $(0.346)$ & $(0.355)$ & $(0.107)$ & $(0.278)$ & $(0.312)$ & $(0.161)$ & $(0.349)$ & $(0.323)$ & $(0.164)$ & $(0.370)$ & $(0.373)$ \\
\hline Remittances x Recent & 0.032 & 0.087 & 0.107 & 0.043 & 0.070 & 0.080 & 0.018 & 0.032 & 0.125 & 0.106 & 0.066 & 0.070 & -0.135 & -0.058 & -0.012 \\
\hline \multirow[t]{2}{*}{ Remittances x Non-Migrant } & -0.191 & -0.212 & -0.302 & $-0.337^{* * *}$ & $-0.536^{*}$ & $-0.561^{*}$ & 0.128 & 0.014 & -0.124 & -0.182 & -0.342 & -0.482 & -0.259 & 0.008 & 0.027 \\
\hline & $(0.132)$ & $(0.244)$ & $(0.244)$ & $(0.107)$ & $(0.299)$ & $(0.305)$ & $(0.287)$ & $(0.498)$ & $(0.477)$ & $(0.182)$ & $(0.307)$ & $(0.301)$ & $(0.285)$ & $(0.372)$ & $(0.379)$ \\
\hline \multicolumn{16}{|l|}{ Group effect $^{(\$)}$} \\
\hline \multirow[t]{2}{*}{ Recent } & $0.063^{* * *}$ & $0.039^{*}$ & $0.039^{*}$ & $0.082^{* * *}$ & 0.050 & $0.054^{*}$ & $0.046^{* *}$ & 0.033 & 0.023 & $0.087^{* * *}$ & $0.062^{* *}$ & $0.055^{\star}$ & $0.053^{* *}$ & 0.044 & 0.047 \\
\hline & $(0.017)$ & $(0.022)$ & $(0.022)$ & $(0.026)$ & $(0.032)$ & $(0.032)$ & $(0.023)$ & $(0.027)$ & $(0.028)$ & $(0.024)$ & $(0.030)$ & $(0.030)$ & $(0.026)$ & $(0.032)$ & $(0.032)$ \\
\hline Non-Migrant & $0.055^{\star * *}$ & 0.034 & $0.037^{*}$ & $0.044^{*}$ & 0.016 & 0.020 & $0.063^{\star *}$ & $0.053^{*}$ & $0.048^{*}$ & 0.033 & 0.008 & 0.003 & $0.092^{* * *}$ & $0.084^{* * *}$ & $0.089^{* * *}$ \\
\hline $\mathbf{N}$ & 5,344 & 5,344 & 5,344 & 5,344 & 5,344 & 5,344 & 5,344 & 5,344 & 5,344 & 5,344 & 5,344 & 5,344 & 5,344 & 5,344 & 5,344 \\
\hline
\end{tabular}

All estimations control for household characteristics and province effects. Remittance amounts are in CFA divided by 1,000,000.

(a) Coefficients report the effect of remittance receipt (amounts, including zeros) on child labour.

(\$) Reference group: permanent migrant households

Instruments: IV1 is mean expected earnings over 2007-2009; IV2 is the labour shock in 2009.

${ }^{* * *}$, ${ }^{* *}$, and ${ }^{*}$ indicate significant at $1 \%, 5 \%$, and $10 \%$ respectively.

Source: Migration and Remittances Household Survey, Burkina Faso, 2010 


\section{Conclusion}

This paper suggests a first investigation of the effect of remittances on child labour in Africa. The analysis draws upon a unique survey on migrants and their families in Burkina Faso. We focus on rural households with children aged 5-14. We estimate the effect of remittance receipt, instrumented by economic conditions at destination, on child work. We find no clear effect on average but a significantly negative effect among permanent migrant households, for whom the disruptive effect of migration may no longer be felt. In this group, average remittance levels reduce household proportion of working children by $5-11 \%$. There is no evidence of a similar effect among recent migrant households, who additionally suffer from the absence of the migrant. This disruptive effect from migration may explain (some of) the larger rate of child labour in this group. Remittances do not significantly affect child labour either in non-migrant households, possibly characterized by very different remittance behaviour.

The remittance effect does not vary with child gender but seems to be driven mainly by the younger group, indicating a gradual integration of children into work activities and the relatively inelastic labour supply of older children. This finding may carry strong policy implication. Indeed, redistribution towards poor rural households in Burkina Faso may not be effective in reducing child labour among older children. More generally, curbing child labour in an African context may require deeper and longer-term changes in traditional societies along with more profound economic transformations.

Further work should attempt to better understand the overall decision process of the extended family. Notably, it seems necessary to assess who, among family members, is sent abroad and which types of sorting process induce migrants to settle in specific destination areas or become permanent migrants. Indeed, as modestly addressed in the present paper, the migration decision is directly related to motives and usages of remittance transfers. 


\section{References}

Acharya, C. P. and Leon-Gonzalez, R. (2013), How do Migration and Remittances Affect Human Capital Investment? The Effects of Relaxing Information and Liquidity Constraints, Journal of Development Studies, 1-17.

Acosta, P. (2011), School attendance, Child Labour, and Remittances from International Migration in El Salvador, Journal of Development Studies, 47(6), 913-936.

Adams R.H. and Cuecuecha A. (2013), The Impact of Remittances on Investment and Poverty in Ghana, World Development, 50, 24-40.

Alcaraz C., Chiquiar D. and Salcedo A. (2012), Remittances, Schooling, and Child Labour in Mexico, Journal of Development Economics, 97(1), 156-165.

Amuedo-Dorantes C. and Pozo S. (2010), Accounting for Remittance and Migration Effects on Children's Schooling, World Development, 38(12), 1747-1759.

Amuedo-Dorantes, C., A. Georges and S. Pozo (2010), Migration, remittances and children's schooling in Haiti, Annals of the American Academy of Political and Social Science, 630 (1), 224-244.

Antman, F.M., (2011a), The intergenerational effects of paternal migration on schooling and work: What can we learn from children's time allocations? Journal of Development Economics, 96(2), 200-08.

Antman, F.M., (2011b), International migration and gender discrimination among children left behind, American Economic Review, 101(3), 645-49.

Antman, F.M., (2012), Gender, Educational Attainment, and the Impact of Parental Migration on Children Left Behind, Journal of Population Economics, 25, 1187-1214.

Bansak, C., and Chezum, B. (2009), How Do Remittances Affect Human Capital Formation of School-Age Boys and Girls? American Economic Review, 99(2), 145-48.

Basu, K. and Van, P.H. (1998), The Economics of Child Labour, American Economic Review, $88(3), 412-427$.

Basu, K., Das, S. and B. Dutta. (2010), Child labor and household wealth: Theory and empirical evidence of an inverted-U, Journal of Development Economics, 91(1), 8-14.

Beegle K., Dehejia R. and Gatti R. (2006), Child Labour and Agricultural Shocks, Journal of Development Economics, 81(1), 80-96.

Bhalotra, S. and Heady, C. (2003), Child farm labor: The wealth paradox, The World Bank Economic Review, 17(2), 197-227.

Boutin, D. (2012), Family farming, child labour and the wealth paradox: evidence from Mali, Economics Bulletin, 32(4), 3471-3479. 
Calero, C., Bedi S. and Sparrow R. (2009), Remittances, Liquidity Constraints and Human Capital Investments in Ecuador, World Development, 37(6), 1143-54.

Cox Edwards, A. and Ureta, M. (2003), International Migration, Remittances, and Schooling: Evidence from El Salvador, Journal of Development Economics, 72(2), 429461.

Dumas, C. (2007), Why do parents make their children work? A test of the poverty hypothesis in rural areas of Burkina Faso, Oxford Economic Papers, Oxford University Press, vol. 59(2), pages 301-329.

Dumas, C. (2013), "Market Imperfections and Child Labor," World Development, vol. 42(C), pages 127-142.

Ebeke, C.H. (2010), The effect of remittances on child labour: Cross-Country Evidence, Economics Bulletin, Volume 30, issue 1, 351-364.

Edmonds, E. and Pavcnik, N. (2005), Child Labor in the Global Economy, Journal of Economic Perspectives, 19(1): 199-220.

Edmonds, E., (2006), Child labor and schooling responses to anticipated income in South Africa, Journal of Development Economics, vol. 81(2), pages 386-414.

Freije, S. and L. F. Lopez-Calva (2000), Child Labor, Poverty and School Attendance in Mexico and Venezuela, El Colegio de Mexico, Working Paper.

Hanson, G.H. and Woodruff, C. (2003), Emigration and educational attainment in Mexico, Working paper, University of California, San Diego.

International Labour Organisation (ILO) (2013), Global Child Labour Trends 2008-2012, September 2013, Geneva.

Lucas, R. (2004), Life Earnings and Rural-Urban Migration, Journal of Political Economy, 112(S1), S29-S59.

McKenzie, D. and Rapoport, H. (2011), Can migration reduce educational attainments? Evidence from Mexico, Journal of Population Economics, 24(4), 1331-58.

Plaza, S., Navarrete, M. and Ratha D. (2011), Migration and Remittances Household Surveys: Methodological Issues and New Findings from Sub-Saharan Africa, The World Bank, Washington D.C.

Rapoport, H. and Docquier, F. (2006), The Economics of Migrants' Remittances, Handbook on the Economics of Giving, Reciprocity and Altruism, Elsevier.

Ratha, D. (2005), Worker's Remittances: An Important and Stable Source of External Development Finance, in Maimbo, Ratha (ed.) Remittances, Development Impact and Future Prospects. Washington: World Bank, 19-52. 
Rosenzweig, M. and Wolpin, K. (1985), Specific experience, household structure, and intergenerational transfers: farm family land and labor arrangements in developing countries, Quaterly Journal of Economics 100, 961-987.

World Bank (2010), Leveraging Migration for Africa: Remittances, Skills and Investments, March 2011.

Yang, D. (2008), International Migration, Remittances and Household Investment Evidence from Philippine Migrants’ Exchange Rate Shocks, Economic Journal, 118(528), 591-630. 


\section{Appendix A: Descriptive Statistics and Complete Estimation Table}

Fig A.1: Age Distribution of Children among Migrant Households

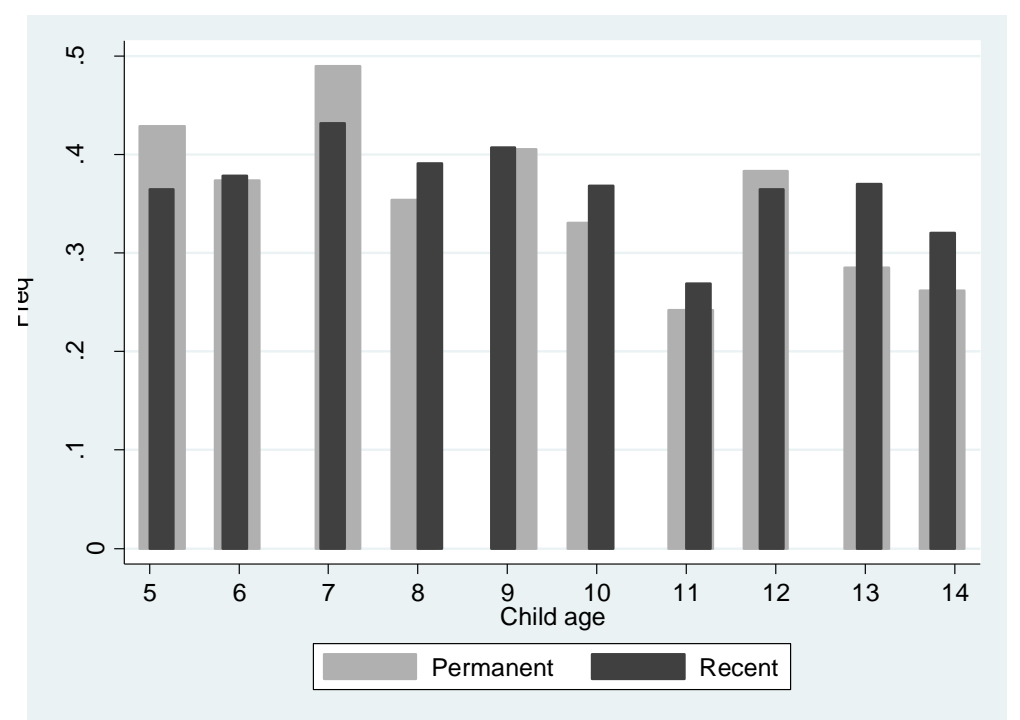

Table A.1: Remittances' Characteristics

\begin{tabular}{|c|c|c|c|}
\hline & \multicolumn{2}{|c|}{ Migrant households } & \multirow{2}{*}{$\begin{array}{l}\text { Non migrant } \\
\text { households }\end{array}$} \\
\hline & Permanent & Recent & \\
\hline \multicolumn{4}{|l|}{ Channels (\%) } \\
\hline Friends & 60.1 & 66.4 & 41.4 \\
\hline Brought back himself & 22.0 & 18.0 & 40.4 \\
\hline Formal institutions (Bank. Western Union) & 12.2 & 10.0 & 14.1 \\
\hline Courier & 2.6 & 2.8 & 1.0 \\
\hline Informal individual & 3.2 & 2.4 & 3.0 \\
\hline Others & 0.0 & 0.4 & 0.0 \\
\hline \multicolumn{4}{|l|}{ Use of Remittances (\%) } \\
\hline Food & 55.9 & 57.2 & 57.3 \\
\hline Education & 8.1 & 7.2 & 9.4 \\
\hline Health & 6.8 & 10.3 & 6.3 \\
\hline Marriage & 3.0 & 3.3 & 2.6 \\
\hline Home & 6.5 & 2.7 & 2.6 \\
\hline Business & 4.6 & 2.4 & 4.2 \\
\hline Others & 9.6 & 12.2 & 11.4 \\
\hline$\%$ unspent (savings) & 5.7 & 4.7 & 6.4 \\
\hline No. of households & 454 & 594 & 578 \\
\hline
\end{tabular}

All statistics refer to the selected sample (rural households with children aged 5-14)

Source: Migration and Remittances Household Survey, Burkina Faso, 2010 
Table A.2: Household-level Estimations of the Proportion of Working Children

\begin{tabular}{|c|c|c|c|}
\hline & OLS & IV1 & IV2 \\
\hline \multirow[t]{2}{*}{ Remittances x Permanent } & $-0.338^{* * *}$ & $-0.636^{* \star}$ & $-0.689^{* * *}$ \\
\hline & $(0.129)$ & $(0.256)$ & $(0.266)$ \\
\hline \multirow[t]{2}{*}{ Remittances x Recent } & -0.080 & -0.193 & -0.178 \\
\hline & $(0.098)$ & $(0.193)$ & $(0.191)$ \\
\hline \multirow[t]{2}{*}{ Remittances $x$ Non-Migrant } & -0.201 & -0.163 & -0.236 \\
\hline & $(0.195)$ & $(0.285)$ & $(0.303)$ \\
\hline \multirow[t]{2}{*}{ Recent (\$) } & $0.060^{* * *}$ & $0.050^{* *}$ & $0.047^{\star *}$ \\
\hline & $(0.018)$ & $(0.022)$ & $(0.022)$ \\
\hline \multirow[t]{2}{*}{ Non-Migrant (\$) } & $0.041^{* *}$ & 0.027 & 0.025 \\
\hline & $(0.018)$ & $(0.021)$ & $(0.021)$ \\
\hline \multirow[t]{2}{*}{ Household size } & -0.000 & -0.000 & -0.000 \\
\hline & $(0.003)$ & $(0.003)$ & $(0.003)$ \\
\hline \multirow[t]{2}{*}{ \# children 5-14 } & 0.002 & 0.002 & 0.002 \\
\hline & $(0.007)$ & $(0.007)$ & $(0.007)$ \\
\hline \multirow[t]{2}{*}{ Log of household expenditure } & 0.009 & 0.010 & 0.009 \\
\hline & $(0.008)$ & $(0.009)$ & $(0.009)$ \\
\hline \multirow[t]{2}{*}{ Asset index } & $-0.016^{* * *}$ & $-0.016^{* * *}$ & $-0.016^{\star * *}$ \\
\hline & $(0.004)$ & $(0.004)$ & $(0.004)$ \\
\hline \multirow[t]{2}{*}{ Moslim } & 0.008 & 0.008 & 0.008 \\
\hline & $(0.018)$ & $(0.018)$ & $(0.018)$ \\
\hline \multirow[t]{2}{*}{ Mossi ethnic group } & $-0.084^{* * *}$ & $-0.083^{* * *}$ & $-0.083^{* * *}$ \\
\hline & $(0.023)$ & $(0.023)$ & $(0.023)$ \\
\hline \multirow[t]{2}{*}{ Age of household head } & 0.001 & 0.001 & 0.001 \\
\hline & $(0.001)$ & $(0.001)$ & $(0.001)$ \\
\hline \multirow[t]{2}{*}{ Female headship (\%) } & $-0.108^{* * *}$ & $-0.106^{\star * *}$ & $-0.106^{\star \star *}$ \\
\hline & $(0.040)$ & $(0.041)$ & $(0.041)$ \\
\hline \multirow[t]{2}{*}{ Head is employed $(\%)$} & $0.171^{* * *}$ & $0.170^{\star \star *}$ & $0.170^{\star * *}$ \\
\hline & $(0.048)$ & $(0.048)$ & $(0.048)$ \\
\hline \multirow[t]{2}{*}{ Head has no education (\% ) } & $0.138^{* * *}$ & $0.138^{* * *}$ & $0.138^{* * *}$ \\
\hline & $(0.027)$ & $(0.027)$ & $(0.027)$ \\
\hline \multirow[t]{2}{*}{ \# adults employed per village } & $0.000^{* * *}$ & $0.000^{* * *}$ & $0.000^{* * *}$ \\
\hline & $(0.000)$ & $(0.000)$ & $(0.000)$ \\
\hline \multirow[t]{2}{*}{ \# migrants per village } & -0.000 & -0.000 & -0.000 \\
\hline & $(0.000)$ & $(0.000)$ & $(0.000)$ \\
\hline \multirow[t]{2}{*}{ Constant } & -0.207 & -0.215 & -0.214 \\
\hline & $(0.147)$ & $(0.149)$ & $(0.149)$ \\
\hline Province dummies: $p$ value of joint significance & 0.000 & 0.000 & 0.000 \\
\hline R2 & 0.161 & 0.160 & 0.160 \\
\hline $\mathrm{N}$ & 1,627 & 1,627 & 1,627 \\
\hline \multicolumn{4}{|c|}{ Remittance amounts (incl. zeros) are in CFA divided by $1,000,000$. } \\
\hline \multicolumn{4}{|c|}{$\begin{array}{l}\text { Instrument: IV1 is expected earnings in migration region over 2007-2009; IV2 is the labour shock in } 2009 \\
\text { (\$) Reference group: permanent migrant households }\end{array}$} \\
\hline
\end{tabular}

Source: Migration and Remittances Household Survey, Burkina Faso, 2010 


\section{Appendix B: Robustness Checks}

Table B.1: Impact of Remittances Receipt on Child Labour when Varying the Sample (Household-level Estimations) Dep. variable: Propotion of children at Exclusive of urban-to-rural and rural-to- $\quad$ Exclusive of domestic migration work in the household urban migration

\begin{tabular}{|c|c|c|c|c|c|c|}
\hline & OLS & IV1 & IV2 & OLS & IV1 & IV2 \\
\hline \multicolumn{7}{|c|}{ Heterogenous remittance effects ${ }^{\text {(a) }}$} \\
\hline \multirow[t]{2}{*}{ Remittances x Permanent } & $-0.371^{* *}$ & $-0.832^{\star * *}$ & $-0.828^{* * *}$ & $-0.416^{\star *}$ & $-0.896^{\star \star *}$ & $-0.963^{* * *}$ \\
\hline & $(0.158)$ & $(0.270)$ & $(0.284)$ & $(0.165)$ & $(0.271)$ & $(0.291)$ \\
\hline \multirow[t]{2}{*}{ Remittances $x$ Recent } & -0.073 & -0.086 & -0.034 & 0.019 & 0.059 & 0.045 \\
\hline & $(0.124)$ & $(0.236)$ & $(0.232)$ & $(0.137)$ & $(0.253)$ & $(0.256)$ \\
\hline \multirow[t]{2}{*}{ Remittances x Non-Migrant } & -0.209 & -0.014 & -0.043 & -0.194 & 0.035 & 0.014 \\
\hline & $(0.243)$ & $(0.313)$ & $(0.325)$ & $(0.260)$ & $(0.312)$ & $(0.315)$ \\
\hline \multicolumn{7}{|l|}{ Group effect $^{(\$)}$} \\
\hline \multirow[t]{2}{*}{ Recent } & $0.065^{\star * *}$ & 0.042 & 0.039 & $0.059^{* *}$ & 0.028 & 0.025 \\
\hline & $(0.023)$ & $(0.028)$ & $(0.028)$ & $(0.027)$ & $(0.033)$ & $(0.033)$ \\
\hline \multirow[t]{2}{*}{ Non-Migrant } & 0.026 & 0.001 & 0.001 & 0.014 & -0.017 & -0.021 \\
\hline & $(0.022)$ & $(0.025)$ & $(0.025)$ & $(0.025)$ & $(0.028)$ & $(0.029)$ \\
\hline $\mathbf{N}$ & 1,311 & 1,311 & 1,311 & 1,056 & 1,056 & 1,056 \\
\hline \multicolumn{7}{|c|}{ All estimations control for household characteristics and province effects. Remittance amounts are in CFA divided by 1,000,000. } \\
\hline \multicolumn{7}{|c|}{ (a) Coefficients report the effect of remittance receipt (amounts, including zeros) on child labour. } \\
\hline \multicolumn{7}{|c|}{ (\$) Reference group: permanent migrant households } \\
\hline \multicolumn{7}{|c|}{ Instruments: IV1 is mean expected earnings over 2007-2009; IV2 is the labour shock in 2009.} \\
\hline \multicolumn{7}{|c|}{${ }^{* * *},{ }^{* *}$, and ${ }^{*}$ indicate significant at $1 \%, 5 \%$, and $10 \%$ respectively. } \\
\hline
\end{tabular}

Source: Migration and Remittances Household Survey, Burkina Faso, 2010 
Table B.2: Impact of Remittances Receipt on Child Labour Varying "Permanent/Recent Migrant" Definition (Household-level Estimations)

\begin{tabular}{|c|c|c|c|c|c|c|c|c|c|c|c|c|c|c|c|}
\hline \multirow[t]{2}{*}{$\begin{array}{l}\text { Dep. variable: Propotion of children at } \\
\text { work in the household }\end{array}$} & \multicolumn{3}{|c|}{ 3-year threshold } & \multicolumn{3}{|c|}{ 4-year threshold } & \multicolumn{3}{|c|}{ 5-year threshold } & \multicolumn{3}{|c|}{ 6-year threshold } & \multicolumn{3}{|c|}{ 7-year threshold } \\
\hline & OLS & IV1 & IV2 & OLS & IV1 & IV2 & OLS & IV1 & IV2 & OLS & IV1 & IV2 & OLS & IV1 & IV2 \\
\hline
\end{tabular}

\section{Heterogenous remittance effects ${ }^{(a)}$}

\begin{tabular}{|c|c|c|c|c|c|c|c|c|c|c|c|c|c|c|c|}
\hline \multirow[t]{2}{*}{ Remittances x Permanent } & $-0.252^{* *}$ & $-0.472^{* *}$ & $-0.427^{\star}$ & $-0.224^{*}$ & $-0.465^{*}$ & -0.410 & $-0.254^{*}$ & $-0.734^{* * *}$ & $-0.702^{* * *}$ & $-0.278^{*}$ & $-0.624^{* *}$ & $-0.601^{* *}$ & -0.228 & $-0.579^{* *}$ & $-0.559^{*}$ \\
\hline & $(0.104)$ & $(0.239)$ & $(0.244)$ & $(0.116)$ & $(0.251)$ & $(0.259)$ & $(0.137)$ & $(0.258)$ & $(0.271)$ & $(0.145)$ & $(0.278)$ & $(0.293)$ & $(0.146)$ & $(0.283)$ & $(0.299)$ \\
\hline \multirow[t]{2}{*}{ Remittances x Recent } & 0.124 & 0.028 & 0.061 & 0.019 & 0.058 & 0.079 & -0.010 & 0.036 & 0.056 & -0.017 & 0.125 & 0.159 & -0.041 & 0.227 & 0.263 \\
\hline & $(0.121)$ & $(0.238)$ & $(0.241)$ & $(0.110)$ & $(0.219)$ & $(0.217)$ & $(0.101)$ & $(0.199)$ & $(0.198)$ & $(0.096)$ & $(0.216)$ & $(0.214)$ & $(0.095)$ & $(0.220)$ & $(0.217)$ \\
\hline \multirow[t]{2}{*}{ Remittances x Non-Migrant } & -0.215 & -0.172 & -0.243 & -0.216 & -0.176 & -0.247 & -0.216 & -0.186 & -0.258 & -0.216 & -0.176 & -0.246 & -0.216 & -0.179 & -0.250 \\
\hline & $(0.200)$ & $(0.296)$ & $(0.315)$ & $(0.201)$ & $(0.296)$ & $(0.315)$ & $(0.201)$ & $(0.294)$ & $(0.312)$ & $(0.201)$ & $(0.295)$ & $(0.313)$ & $(0.201)$ & $(0.296)$ & $(0.315)$ \\
\hline \multicolumn{16}{|l|}{ Group effect ${ }^{(\$)}$} \\
\hline \multirow[t]{2}{*}{ Recent } & $0.082^{* * *}$ & $0.078^{\star \star *}$ & $0.078^{\star \star \star}$ & $0.084^{* \star *}$ & $0.071^{* * *}$ & $0.072^{* \star *}$ & $0.082^{* * *}$ & $0.057^{* *}$ & $0.057^{* *}$ & $0.083^{* * *}$ & $0.064^{* * *}$ & $0.063^{\star * *}$ & $0.086^{* \star *}$ & $0.050^{* *}$ & $0.049^{*}$ \\
\hline & $(0.018)$ & $(0.023)$ & $(0.023)$ & $(0.018)$ & $(0.023)$ & $(0.023)$ & $(0.019)$ & $(0.023)$ & $(0.023)$ & $(0.019)$ & $(0.024)$ & $(0.025)$ & $(0.018)$ & $(0.025)$ & $(0.026)$ \\
\hline \multirow[t]{2}{*}{ Non-Migrant } & $0.058^{* * *}$ & $0.045^{\star *}$ & $0.048^{\star *}$ & $0.059^{* \star *}$ & $0.045^{\star *}$ & $0.048^{* *}$ & $0.058^{* * *}$ & 0.035 & $0.038^{*}$ & $0.058^{* * *}$ & $0.046^{* *}$ & $0.048^{* *}$ & $0.061^{* * *}$ & $0.041^{*}$ & $0.043^{*}$ \\
\hline & $(0.019)$ & $(0.020)$ & $(0.020)$ & $(0.019)$ & $(0.021)$ & $(0.021)$ & $(0.019)$ & $(0.022)$ & $(0.022)$ & $(0.019)$ & $(0.023)$ & $(0.023)$ & $(0.019)$ & $(0.024)$ & $(0.025)$ \\
\hline $\mathbf{N}$ & 1,627 & 1,627 & 1,627 & 1,627 & 1,627 & 1,627 & 1,627 & 1,627 & 1,627 & 1,627 & 1,627 & 1,627 & 1,627 & 1,627 & 1,627 \\
\hline
\end{tabular}

All estimations control for household characteristics and province effects. Remittance amounts are in CFA divided by 1,000,000.

(a) Coefficients report the effect of remittance receipt (amounts, including zeros) on child labour.

(\$) Reference group: permanent migrant households

Instruments: IV1 is mean expected earnings over 2007-2009; IV2 is the labour shock in 2009.

${ }^{* * *},{ }^{* *}$, and ${ }^{*}$ indicate significant at $1 \%, 5 \%$, and $10 \%$ respectiv ely.

Source: Migration and Remittances Household Survey, Burkina Faso, 2010 
${ }^{1}$ Migrants are most often the head's children or siblings so recall bias are unlikely. Arguably, this may occur for other relatives that lived in the household a long time ago.

${ }^{2}$ We use the question about the number of months/years since the migrant left the household for the last time, according to the household head. This way, our results are not affected by circular migration.

${ }^{3}$ Given the high costs of migration, wealthier households may be more able to send their migrants to the most attractive regions and ensure that they will receive remittances.

${ }^{4}$ Other papers make a different exclusion restriction, notably Antman (2011a) who uses labour market conditions to instrument the migration decision rather than remittance receipts. More generally, endogeneizing remittances, migration decision and migration duration is clearly beyond the scope of our paper due to the difficulty to find mutually exclusive instruments. Beyond identification problems, it also seems difficult to think of instruments for migration duration. The migration literature has suggested instruments in the case of return migration, which is not the relevant dimension here since all migrants are still in destination regions. In other words, migration duration varies only with respect to the time of departure, not the time of return. As a matter of fact, very few households in our data declare having returnees. Hence, permanent and recent migrants are not fundamentally different in their intention of return and - for this reason at least in their remittance behaviour.

${ }^{5}$ The complete table of estimates is shown in Table A2 in the Appendix for the baseline specification (OLS, IV1 and IV2 household-level estimations of the proportion of working children on controls and heterogeneous remittance effects using remittance amounts including zeros). Complete estimation tables for other specifications are available upon request.

${ }^{6}$ Several studies also show that migration mitigates the positive impact of remittances on child human capital (Alcaraz et al., 2012, McKenzie and Rapoport, 2011). Antman (2011a) finds a negative effect of paternal migration on study hours for boys within the first year after the migration took place, when it might be too early to expect a positive effect from remittances to outweigh the father's absence from the home.

${ }^{7}$ Hotelling tests on the joint difference of all household characteristics do not reject the null hypothesis of equal characteristics.

${ }^{8}$ Coefficients on the dummies for the different categories of relationships are all insignificant individually (except the category "grand-parents" which is almost significant at $10 \%$, i.e. p-value of 0.102 with OLS and 0.108 with IV2) and jointly (p-value larger than 0.32 for OLS, IV1 and IV2).

${ }_{9}$ At migrant departure, almost all recent migrant households had a child and the average age of children was 9.8 ( $95 \%$ of them were in the 5-14 age bracket). In contrast, only $70 \%$ of permanent migrant households had a child at departure and if so, average children age was only 4.4 (48\% of children were in the 5-14 age range and others below).

${ }^{10}$ Understandably, the group effect disappears in this case as child age at departure is calculating using current child age and migration duration. More generally, the additional controls suggested above (migrant's relationship to children and child age at departure) represent migrants' characteristics which are deemed endogenous to the amount of remittances (and possibly to household types), hence were not included in our baseline estimations.

${ }^{11}$ Admittedly, we cannot use very small (resp. large) cut-offs, which would lead to a very small sample of recent (resp. permanent) migrant households.

${ }_{12}$ Adding controls variables related to children's characteristics - age, age squared, gender and birth rank - does not affect the coefficients on the variable of interest in any particular way.

${ }^{13}$ In the presence of incomplete labour markets, households may require the help of their older children to perform complex tasks (Freije and Lopez-Calva, 2001), so that older child labour may be little elastic to extra resources like remittances.

${ }^{14}$ This may result in relatively low rates of school attendance and an increase in school drop-out from the age of 11 (school attendance is 58\% among children under 10 and 50\% among children aged 11 to 14). 